\title{
MÚSICA E DEFICIÊNCIA: PROPOSTAS PEDAGÓGICAS PARA UMA PRÁTICA INCLUSIVA
}

\author{
Lisbeth SOARES ${ }^{1}$
}

LOURO, V. S. Educação musical e deficiência: propostas pedagógicas. São José dos Campos: Ed. do autor, 2006.

O atendimento à diversidade - em especial às pessoas com necessidades especiais - tem sido amplamente debatido pelos diversos setores da sociedade. No âmbito da educação, muitas são as práticas e as pesquisas que versam sobre este assunto, enfocando a inclusão no contexto da escola regular. Em relação ao ensino de música, no entanto, tal discussão ainda deve ser ampliada, visto que pessoas com necessidades especiais que têm interesse em estudar esta linguagem artística, encontram sérias dificuldades de acesso e, geralmente, não encontram profissionais capacitados para ensinar-lhes música de maneira adequada. O livro "Educação musical e deficiência: propostas pedagógicas", lançado no III Simpósio de Educação Musical Especial ${ }^{2}$ e elaborado com base nas experiências profissionais e acadêmicas da autora e dos co-autores, vem contribuir para este debate, apresentando aspectos teóricos relevantes, além de sugerir diversas atividades práticas.

Organizado em duas partes, o livro parte do pressuposto de que a música deve ser acessível a todos, procurando desfazer a crença de que é necessário ter "dom" ou "talento" para estudar música; também apresenta a discussão sobre as várias possibilidades do fazer musical, ressaltando que "com uma visão mais ampla de música, e não somente focada na performance ${ }^{3}$ instrumental (...)” (p. 30), todas as pessoas podem e devem ser incluídas em tal processo de aprendizagem. Para tanto, a autora destaca a importância do professor, profissional que deve estar em constante pesquisa e investigação a respeito das alternativas metodológicas para o ensino de música para todos.

Na primeira parte, estão presentes informações gerais sobre as deficiências, além de tópicos sobre psicomotricidade e aprendizagem musical, musicoterapia e educação musical, e as adaptações necessárias para a viabilização do fazer musical para as pessoas com necessidades especiais. Este último tópico,

\footnotetext{
${ }^{1}$ Mestre em Educação Especial pela Universidade Federal de São Carlos - soaresl@terra.com.br

${ }^{2}$ O III Simpósio de Educação Musical Especial ocorreu entre os dias 2 e 4/11, em São Paulo. Para maiores informações sobre este evento, acesse www.musicaeinclusao.com.br

${ }^{3}$ Grifo original. 
desenvolvido com base na dissertação da autora, apresenta informações sobre a tecnologia assistiva e discute sobre os diversos tipos de adaptações pedagógicas, tais como adaptações de objetivos e de conteúdos, arranjos musicais e adaptações técnico musicais.

As sugestões de atividades práticas compõem a segunda parte do livro e estão fundamentadas nas metodologias dos importantes educadores musicais do século XX - C. Orff, J. Dalcroze, E. Willems, M. Schafer, V. Gainza - que valorizam as vivências corporais no processo de aprendizagem e de formalização de símbolos e conceitos. No material apresentado, os jogos musicais são o destaque, pois são considerados muito importantes, pela autora, para a aquisição do conhecimento e para a aprendizagem musical de todas as pessoas, independentemente da idade. Em relação às pessoas com necessidades educacionais especiais, os jogos podem, também, favorecer tanto a participação em aula quanto a melhora da auto-estima e do desempenho na família e na sociedade.

Todas as atividades são apresentadas de uma maneira muito organizada, indicando os objetivos, os componentes, o princípio da atividade e as adaptações, observações e resultados obtidos na aplicação das mesmas, considerando a prática profissional da autora. Ao final do livro é apresentada, ainda, uma tabela contendo o resumo das atividades e os aspectos musicais, psicomotores e outros desenvolvidos, o que favorece a atuação do professor.

Por fim, o livro Educação musical e deficiência: propostas pedagógicas vem colaborar com a comunidade científica voltada para este assunto, visto que são poucas as referências nesta área, contribuindo para o aprimoramento das práticas musicais e artísticas realizadas com as pessoas com necessidades especiais e enriquecendo os debates neste sentido. 